\title{
THE DEVELOPMENT OF PSYCHIATRY AND PSYCHOANALYSIS IN POST-TOTALITARIAN AND TRANSITIONAL SOCIETIES
}

\author{
Mikhail M. Reshetnikov \\ East-European Psychoanalytic Institute \\ Saint Petersburg
}

\begin{abstract}
The author analyzes in brief the historical development of psychiatry, psychology and psychotherapy in Soviet Union and pots-Soviet Russia. He expresses his view on modern state of affairs between state and private practice and gives a detailed account of the formation of modern Russian psychoanalytic community and its entry into the international community.

Keywords: psychology and psychotherapy in Soviet Union and Russia, psychiatrists, psychologists, psychotherapists, state and private medicine, psychoanalysis and psychoanalytic community, psychoanalytic training and education, European Confederation of Psychoanalytic Psychotherapies.
\end{abstract}

This paper mostly covers Russian experience. But, there are some reasons to believe that all post-Soviet countries share the same problems and specific features.

In Soviet times (till the end of 1970s) psychiatric textbooks would state that there were no neuroses in the USSR, because the USSR, as it had been declared, was a new type of society, which had no social basis for neurosis - the disease of "the rotten West." Psychology, psychotherapy and psychoanalysis were suppressed in the USSR in 1930s, because they release individual's potentials and bring him freedom, which the new power could not possibly accept. All types of psychic activity would be attributed to reflexes, the theory developed by academic Pavlov. It may be difficult for our Western colleagues to realize, that before 1966 we had had no such profession as psychologist, that specialty of psychotherapist appeared on the list only after 1985.

Then in 1966 the situation changed. The reason was not humanization of the society but rather technical progress. New psychological knowledge was demanded. So in 1966 the first psychological departments were 
The Development of Psychiatry and Psychoanalysis in Post-totalitarian ... Societies 647

founded in Soviet Universities. Psychotherapy was introduced to medicine in 1975, but it was merely a kind of experiment. Positions of psychotherapists were installed in state clinics, but there were only two hundred psychotherapists in the whole country. Russian population at the time numbered two hundred and twenty million. There was no educational system for psychotherapists, as no opportunity to adopt experience of other countries. In 1983 the main Russian psychiatric association, the All-Union Society of Psychiatrists and Narcologists resigned from the World Psychiatric Association before it could be expelled for practicing punitive psychiatry (Bloch, 1990). There had been no connections with foreign psychotherapeutic societies before 1984. Doctors of medicine and public opinion would regard psychotherapy as a kind of small talk or a chat. So, when experimental introduction of psychotherapy began, only the worst general practitioners or surgeons were sent to practice psychotherapy.

Directors of state clinics would think: " $\mathrm{X}$ is an incompetent (let's say) dentist, so I will send him to have a chat with patients." These specialists acquired no psychotherapeutic education and training. So, psychotherapy was perceived as a second-rate profession. Only now, thirty years later, the situation comes to a change.

Experimental introduction of psychotherapy lasted for ten years. Only in 1985 Ministry of Public Health included psychotherapy in the list of medical professions ("Prikaz Ministerstva" 1985). Any medical doctor after one or three months of theoretical education could get a state certificate of psychotherapist. In the process of such training he learned 44 psychotherapeutic methods, so he could declare himself a specialist in any of them, but in reality only hypnosis and rational therapy were used in practice. There were no psychoanalysis, no behavioural therapy, no gestalttherapy. In this eclectic way the first two thousand specialists were trained from 1985 to 2008 . It was called multimodal approach. This kind of training is still employed in Russia. The period of training is longer now, it is about a year, but they still study the same 44 methods of treatment. Such specialists happen to know something about all forty four methods, but have never practiced any of them. Such training doesn't include personal therapy and supervisions. So, most of these specialists got their state certificates without applying these methods to practice, without seeing any patients, without experiencing a patient's role.

Lack of adequate understanding of the situation led to methodological problems and created the staff problem. There are about 16000 psy- 
chiatrists in Russian state clinics now and about 2000 psychotherapists. The ratio is: one psychotherapist to eight psychiatrists. As far as I know, in most Western countries there are five to seven psychotherapists to one psychiatrist. In Russia there has been no legislation in the field of certification of psychotherapists. It led to the fact that thousands of graduates of psychological departments who had no special psychotherapeutic training began to practice "psychotherapy," each according to his/her own idea of the subject (as you may well know, we have no private psychiatry in Russia).

Psychologists also entered the field of private psychotherapeutic practice. It is not regulated by the state law, but it is not forbidden. Psychologists and physicians today come to practice in private setting (as psychotherapists) for many reasons. They can be inspired by a new profession or may strive to fulfil a society demand. But financial aspect is of no less importance.

Psychotherapist in a state clinic sees about 12 patients per day, and his salary is about 200 euros per month. Psychologist or psychotherapist in private practice sees about 4-6 patients per day and he also receives 200 euros, but per day, not per month. The reason for such difference in payment is connected with confidentiality: state therapist must report to his clinic director, private one assumes responsibility before the patient only.

In general, the money psychotherapist earns doesn't depend on his qualification but rather on society's demand for psychotherapy. The level of this demand is very high, as it usually happens when society attempts dramatic reforms and people feel traumatized. That is why Russia today swarms with fortune-tellers, wizards, shamans, black and white magicians. Ministry of Health issued official certificates of healers to 300000 (three hundred thousand) of them, and there are many more without any official registration. And there are only 14-16 thousand specialists who had at least minimal training (I mean, psychologists and state psychotherapists), while the country's population numbers one hundred and forty million people. The ratio is: one specialist to ten thousand people. In most western countries, as far as I know, the ratio is: one specialist to about one thousand people. That's why we joke that a psychotherapist will hardly suffer from unemployment in Russia.

In the beginning of 1990s serious problems emerged in Russian mental health care: 1) dramatic growth of psychopathology in population; 2) growing demand for psychotherapy and psychological correction 
The Development of Psychiatry and Psychoanalysis in Post-totalitarian ... Societies 649

among population; 3 ) lack (or, to put it plain, mere absence) of specialists, 4) absence of systematic training for psychotherapists; 5) unprecedented expansion of pharmacological companies which would impose their panacea both on psychiatrists and on patients; 6 ) because of financial difficulties the number of inpatients in mental hospitals decreased by thirty percent. Patients were discharged for outpatient treatment. But the outpatient psychiatric help was not well-developed in this country; 7) psychotherapy in Russia is sub-specialty of psychiatry, so any psychiatrist can declare himself a psychotherapist. Salary of a state psychiatrist is depressively low - about 400 euros per month; that is why the psychiatrists would also take positions of psychotherapists in their clinics (to earn extra money). So, mental hospitals were left without psychotherapists at all.

We (I mean psychoanalysts) had yet another problem: the status of psychoanalysis treatment was very low, it was perceived as "too much sexualized and outdated." All our further steps were directed at the solution of these problems.

Since 1988 the first psychotherapeutic associations have appeared in Russia, most of them psychoanalytically oriented. They would meet ironic and a somewhat aggressive reaction. In 1989 professor Rozhnov, a prominent psychiatrist in the Soviet hierarchy told me: "Don't hurry. All of you, psychoanalysts, will be in jail before long." But psychoanalysis was accepted with great interest in society and non-state psychotherapeutic circles.

After the foundation of first psychoanalytic societies we established relationships with our European and American colleagues. We also translated and published the principal works of Freud and his followers. We focused on public psychological education; we tried to avoid speaking psychoanalytic jargon difficult for understanding even for colleagues, we would rather speak common language as the first psychoanalysts used to. When we addressed governmental officers we did the same. In 1998 total amount of psychoanalytic literature published in Russia was fifty million copies. In former times only Lenin's works had been published in such amounts. Before that, Freud's ideas were criticized by scientists who had never read his books. People, who were inspired by psychoanalysis in the end of 1980s read Freud's works photocopied from old editions (published in the beginning of the $20^{\text {th }}$ century). So, it is not correct to say that psychoanalysis was completely destroyed in the USSR. It went underground but it survived. Many of my friends used to be such underground Freud- 
ians. In 1991 the first private psychoanalytic university was founded. It provided students with four years of psychoanalytical education. It was to give theoretical knowledge meant for people with higher education. But in 1996 an institution of professional training was established. It included personal analysis and supervisions. The standards of professional training were set for three statuses: specialist, training analyst and supervisor.

At the same time the first psychoanalytic clinics were opened. Let me point out that in 1996 we had about six patients a day, and now at our Psychoanalytic University in Saint Petersburg specialists see about 70-100 patients a day. During these years psychoanalytic clinics were opened in Moscow, Khabarovsk, Novosibirsk, Rostov and dozens of other Russian cities and towns. The quality of their work is not the same everywhere, but these are natural problems of growth; the same situation was in Europe in 1930s.

In 1998 we realized that together we could do more, and seventeen psychoanalytic societies in Russia were united into the National Federation of Psychoanalysis. Since then it has become the most influential organization in the field. The Federation has its Statute, Ethical Code, requirements for standards of professional training, requirements for public accreditation of specialists and affiliation of other professional societies.

About one thousand and five hundred specialists have acquired theoretical psychoanalytic education. They work in different spheres in Universities, banks, advertising companies, newspapers, publishing houses, and in business. Today National Psychoanalytic Federation numbers about 400 members now and only 150 of them are in clinical practice. According to statistics of 2008 (12 years since professional training system was established), there were 62 certified specialists, 37 training analysts and 22 supervisors. About one hundred candidates were on their way to get status of specialist.

Our specialists continue their development and accumulation of practical experience, though their present day level is not much different from level of their Western colleagues. Anyway, we speak the same psychoanalytic language - and we understand that the only psychoanalytic language is our practice.

We could not have achieved this if we hadn't got the help from our Western colleagues. For many years we have been assisted by specialists from IPA, IAAP, EPF, NAAP and many national associations from France, Germany, Italy, the UK, the USA and other countries. I could name many 
The Development of Psychiatry and Psychoanalysis in Post-totalitarian ... Societies 651

foreign colleagues, but it would take all the time of my presentation, as hundreds of specialists have visited us and provided us with invaluable help. Some of these specialists would stay working in Russia for years.

Psychoanalysis became second main method of psychotherapy in Russia. Fifteen years ago (1993) 72\% of Russian psychotherapists identified themselves as multimodal, the second were hypnologists $-15 \%$, and $13 \%$ could not identify themselves. Now (to 2008) 57\% are multimodal, $27 \%$ are psychoanalytic or psychodynamic, $24 \%$ are cognitivebehavioural, $17 \%$ are rational therapists, $14 \%$ are suggestive therapists, and $5 \%$ are gestalt-therapists. Totally we have more than one hundred percent here because some therapists chose two approaches from the list. Specialization and development of different directions of psychotherapy are continued.

Ethic atmosphere in Russian psychoanalytic community was influenced by memorandum of our respectable German colleague Professor Horst Kaechele (with doctor Helmut Thomae) about a reform in psychoanalytic education (Thomae \& Kaechele, 1999). Specialists know but I will repeat some of the critics of modern psychoanalytic education and training (from the article by Dr. Otto Kernberg (Kernberg, 1993)). It is over-domination of psychoanalytic institutions, whose traditions and caste structure are perceived as more important than people. In fact, candidates are forced to have long treatment instead of learning their future profession (as if only insane people come to our specialty). As our French colleagues say, to become a psychoanalyst you must be very sick and very rich. It seems that we have overcome these problems to a certain degree and have introduced a number of reforms in professional education and training. In particular:

- Psychoanalytic education and professional training are independent areas in Russia. They are connected only for those who intend to specialize in clinical practice.

- Candidates themselves choose training analysts and supervisors.

- Candidates take an independent decision, whether they should continue their personal analysis after fulfilling standard requirements or not. This idea met a lot of resistance, but now only fifteen percent candidates stop after they meet standards, and eighty five percent continue their personal analysis and they have on the average two-three times more hours than it is required. But it is 
their own choice, and it creates absolutely different ethical climate in professional training area.

- Training committee awards status of specialist to candidates who fulfilled standards of training and got reports about their work from at least three supervisors (two of them are on permanent basis).

- Training committee usually awards statuses of training specialist and then supervisor at least in three years after the previous one on the basis of individual estimation of every candidate. Supervisors estimate a specialist's theoretical education and practice. Personal analyst makes no judgment; he just informs that the candidate fulfilled the standard.

There are certain shortcomings, but we have much more positive results. While psychoanalytic community in Western countries anxiously admits decline of psychoanalysis (for example, six to ten candidates a year come to a typical American psychoanalytic training institute); while professional literature is full of doubts about adequacy of psychoanalysis to contemporary life - our community grows actively. The person who comes to get a new profession should not be treated against his will. Some of our patients visit us for months, some for years. But the person who wants to become a psychoanalyst is inevitably analyzed during a few years. Is he always sicker than other patients? Let me repeat that we have rejected this conservative and even abusive and humiliating system.

What have we achieved in the end of these twenty years? On the average, Russian psychoanalysts are twice younger than their Western colleagues; we have no doubt about the fact that psychoanalysis meets public demand - the number of our patients has increased 15 times in 10 years; there are more than 600 students from eleven countries in our Psychoanalytic University (East European Psychoanalytical Institute), more than 120 of them are at final stages of their professional training. The number of practicing specialists has become 7 times higher within the last 10 years.

While our Western colleagues try to comprehend some incomprehensible processes in society, by which they undermine the status of psychoanalysis, and try to find a way to integration, we started with the analysis of the structure and system of professional training; we refused authoritarian "cast" system, we rejected over-domination of psychoanalytical institutions and we excluded excessive competition between differ- 
ent approaches in psychoanalysis. We've arrived at the honest conclusion: it is not the question of methodology - it is the question of power. It was not too easy to do it.

These ideas were shared by a number of our Western colleagues, I mean a new international association - European Confederation of Psychoanalytic Psychotherapies (ECPP), which was established in Vienna in 2003 by psychoanalysts from Austria, Belgium, Germany, Hungary, Lithuania, France, Ireland, Italy, Romania, Russia, Slovenia, Switzerland, UK and Ukraine. Now we have in this organization a few more countries and I am sure that this tendency will persist. The main principle of our organization is: "Everybody who works with transference and resistance is our colleague" (Faeh, 2004). In 2008 there were more than one hundred members of this international organization in Russia now.

In this presentation I didn't mention many difficulties of modern psychoanalytic movement in Russia. Let me sum up the matter briefly. After twenty years of work we can say that psychoanalytic psychotherapy has become really professional in Russia and we witness a slow process of transition to another level of cooperation between psychiatry and psychotherapy. "Resistance to psychoanalysis" continues, but it is not so intense as it used to be. And it cannot seriously affect the development of psychoanalysis in Russia.

\section{References}

Bloch, S. (1990). Athens and Beyond: Soviet Psychiatric Abuse and the World Psychiatric Association. Psychiatric Bulletin, 14, 129-133.

Faeh, M. (2004). On European Confederation of Psychoanalytic Psychotherapies. Vienna.

Kernberg, O. (1993). Current Status of Psychoanalysis. Journal of the American Psychoanalytic Association, 41, 45-62.

"Materializm i èmpiriokriticizm" - orudie bor'by s reakcionnoj psihologiej (1950) [Materialism and Empirio-Criticism as an Instrument in Struggle with Reactionary Psychology]. In Voprosy psihologii: Filosofskie zapiski. T. 5. Moscow, Leningrad: AN SSSR.

Prikaz Ministerstva zdravoohraneniâ № 750 ot 31.05.1985 "O dal'nejšem soveršenstvovanii psihoterapevtičeskoj pomoŝi naseleniû” (1985) [Ministry of Public Health order 750 "On Further Improvement of Psychotherapeutic Help to the Population" (31/05/1985)].

Thomae, H., \& Kaechele, H. (1999). Memorandum about a Reform of the Psychoanalytic Education. IPA Newsletter, 8, 33-35. 